УДК 159.922.1:07]-057.875

DOI https://doi.org/10.26661/2310-4368/2021-1-11

\title{
СТАТЕВІ ВІДМІННОСТІ У ПЕРЕЖИВАННІ СТУДЕНТСЬКОЮ МОЛОДДЮ ПСИХОЛОГІЧНОЇ БЕЗПЕКИ ПІСЛЯ СПРИЙМАННЯ НОВИН IЗ ЗАСОБІВ МАСОВОЇ ІНФОРМАЦЇ̈
}

\author{
Лісневська А. О. \\ кандидат психологічних наук, дочент, \\ доцент кафедри загальної, вікової та соціальної психологї імені М. А. Скока \\ Національний університет «Чернігівський колегіум» імені Т. Г. Шевченка \\ вул. Гетьмана Полуботка, 53, Чернігів, Украӥна \\ orcid.org/0000-0003-1326-4016 \\ blowball@ukr.net
}

\begin{abstract}
Ключові слова: мас-медіа, новини, психологічна безпека, індивідуально-типологічні властивості, базисні переконання особистості.
\end{abstract}

У статті розглянута проблема змін у переживанні психологічної безпеки студентською молоддю різної статі у результаті контакту зі ЗМІ. Мета статті - виявити статеві відмінності у переживанні студентською молоддю психологічної безпеки після сприймання новин зі 3МІ залежно від індивідуально-типологічних властивостей i базових переконань особистості студентів обох статей. Було використано такі методи, як авторська експрес-анкета, Шкала ситуативної тривожності Ч. Спілберга, Індивідуально-типологічний опитувальник Л. Собчик, Шкала базисних переконань особистості.

Отримані результати свідчать про те, що жінки частіше переживають підвищення відчуття небезпеки після сприймання новин зі 3МІ, ніж чоловіки. Для студентської молоді обох статей основними джерелами отримання новин є їхнє безпосереднє оточення (сім'я, друзі, одногрупники) і такі ЗМІ, як інтернет та телебачення. Водночас жінки частіше отримують новинні повідомлення через телебачення і відчувають більшу довіру до цього ЗМI, ніж чоловіки.

До порушення психологічної безпеки після сприймання новин зі ЗМІ схильні насамперед чоловіки, які мають підвищений рівень особистісної тривожності, і жінки, які реагують на новини підвищенням ситуативної тривожності та які мають вищі показники за такими індивідуальнотипологічними властивостями, як тривожність, сензитивність, ригідність і нижчі - за такими базисними переконаннями, як справедливість і удача. Основні висновки дослідження полягають у тому, що сприймання новин зі ЗМІ спричиняє психологічний відгук у студентської молоді обох статей, який виражається у зниженні в них відчуття психологічної безпеки, проте жінки більш інтенсивно ототожнюють себе з ситуаціями, які висвітлюються у новинах, ніж чоловіки. Певний склад особистості жінок лише підсилює зниження в них відчуття психологічної безпеки, оскільки такі жінки ще до перегляду новин характеризуються більшою сприйнятливістю до зовнішніх впливів і нижчими внутрішніми ресурсами опиратися їм. 


\title{
GENDER DIFFERENCES IN THE STUDENTS' EXPERIENCE OF PSYCHOLOGICAL SAFETY AFTER RECEIVING THE NEWS FROM THE MASS MEDIA
}

\author{
Lisnevska A. 0. \\ Candidate of Psychological Sciences, Associate Professor, \\ Associate Professor at M. A. Skok Department of General, Developmental and Social Psychology \\ T. H. Shevchenko National University "Chernihiv Colehium" \\ Hetmana Polubotka str., 53, Chernihiv, Ukraine \\ orcid.org/0000-0003-1326-4016 \\ blowball@ukr.net
}

Key words: mass-media, news, psychological safety, individual and typological properties, basic beliefs of personality.
The article is dealt with the problem of changes in the experiencing psychological safety by students of different sexes as a result of contact with the media. The aim of the article is to identify gender differences in the students' experience of psychological safety after perceiving the news from the media, depending on the individual and typological properties and basic beliefs of students of both sexes. Methods such as the author's express questionnaire, the State-Trait Anxiety Inventory by Charles Spielberger, the Individual and Typological Questionnaire by L. Sobchyk and the Basic Personality Beliefs Scale were used.

The results show that women are more likely to experience a sense of danger after receiving the news from the media than men. For students of both sexes, the main sources of news are their closest environment (family, friends and classmates) and media such as the Internet and television. At the same time, women are more likely to receive news reports on television and have more trust in the media as a source of information than men.

Psychological safety disorders after receiving news from the media usually occur among the men who have an increased level of personal anxiety and women who respond to news by increasing situational anxiety and who have higher figures on such individual and typological characteristics as anxiety, sensitivity, rigidity and lower figures on such basic beliefs as justice and luck.

The main findings of the study are that the perception of news from the media causes a psychological response among students of both sexes. It is expressed in the decreasing of their psychological safety sense, but women identify themselves with situations shown in the news more intensely than men do. A certain composition of women's personality only intensifies the decrease in their sense of psychological safety, because even before watching the news such women are more susceptible to external influences and have lower internal resources to resist them.
Постановка проблеми. Функціонування людини в інформаційному суспільстві передбачає постійне отримання нової інформації з різних каналів (формальних і неформальних). Інформаційний простір, в якому здійснюється життєдіяльність людини, містить у собі як нові можливості, так і несподівані загрози, пов'язані з безперервним потоком нових повідомлень, що змушує iii постійно переосмислювати, коригувати свої поточні життєві ситуації. Особливе місце серед нових повідомлень займають новини, покликані інформувати людей про важливі події, які так чи інакше стосуються їхнього життя в соціумі. Оскільки новини несуть різну за змістом інфор- мацію, вони можуть порушувати в людей відчуття психологічної безпеки, створювати підстави для маніпулювання їхньою свідомістю.

Вивчення психологічної безпеки займає особливе місце у психологічній науці в XXI ст. Психологічна безпека особистості насамперед визначається як стан захищеності эї психіки від деструктивних зовнішніх і внутрішніх впливів (М. Слюсаревський) [1, с. 282], що забезпечує здатність зберігати стійкість у мінливому середовищі (І. Баєва, М. Баєв) [2, с. 2], захищати свої життєво важливі інтереси (О. Бубнова, О. Куликова) $[3$, с. 1], розвиватися як активний соціальний суб'єкт в умовах інформаційної взає- 
модії з навколишнім середовищем (Г. Вербина) [4, с. 197].

Відповідно до поглядів співробітників Інституту соціальної та політичної психології НАПН України, психологічна безпека особистості $е$ інтегральною характеристикою системи взаємодії «суб'єкт - середовище», у процесі якої складається певна ситуація, яка постає у свідомості людини як конструкт «я-в-ситуації» і яка означується нею як «безпечна - небезпечна». Тому психологічна безпека особистості - це такий психологічний стан, який виникає лише в системі «суб' єкт - середовище» і однозначно не зумовлюється ані властивостями людини, ані властивостями ситуації [1, с. 284-286]. Спираючись на таке розуміння психологічної безпеки, можна припустити, що зміни у відчутті людиною захищеності після сприймання новин зі 3МI виникатимуть у результаті відображення нею подій, які висвітлюються в новинах, залежно від іiі психологічних і соціально-демографічних характеристик.

Аналіз останніх досліджень i публікацій. Існує низка наукових праць, присвячених інформаційно-психологічній безпеці особистості, проте лише поодинокі $з$ них присвячені вивченню статевих відмінностей щодо споживання інформаційної продукції зі ЗМІ та щодо переживання й розуміння психологічної безпеки. Так, Г. Шевчук вказує, що чоловіки і жінки дещо по-різному сприймають телевізійні повідомлення: чоловіча аудиторія прагне цілісно охопити висвітлюване явище, зіставити почуте повідомлення 3 іншими відомими фактами; жіноча аудиторія сприймає інформацію менш критично і більш фрагментарно. Такі особливості жіночого сприймання масової інформації пов'язані 3 тим, що жінки більше цікавляться життям інших людей, більше піддаються емоціям, більш чутливі до вербальних впливів і образу комунікатора [5].

Також було виявлено, що чоловіки і жінки надають різного значення цінності «безпека» і по-різному уявляють собі, що являє собою психологічна безпека. Зокрема, І. Ржанова і О. Алексєєва зазначають, що цінність «безпека» у мотиваційно-ціннісній сфері жінок займає вище місце, ніж у чоловіків [6]. Водночас Н. Харламенкова вказує, що у представників обох статей психологічна безпека асоціюється насамперед із потребою у самозбереженні та зі здоров'ям.

Але $є$ й певні відмінності, як чоловіки і жінки уявляють собі, що означає перебувати в стані психологічної безпеки. Якщо для чоловіків психологічна безпека тісно пов'язана 3 внутрішнім досвідом і впевненістю у собі, зі своїми вміннями i можливостями, то для жінок - із почуттями любові, довіри, відсутністю страху, можливостями оточення (надійні друзі, житло). Отже, при відновленні відчуття психологічної безпеки чоловіки орієнтуються передусім на активні стратегії поведінки, жінки - на пасивні [7, с. 54-56].

Оскільки й досі залишається маловивченим, який відгук у психологічному світі осіб різної статі спричиняють новинні повідомлення зі 3МI, й було вирішено дослідити, як змінюється відчуття психологічної безпеки у чоловіків і жінок після сприймання цих новинних повідомлень і як це пов'язано $з$ деякими їхніми психологічними характеристиками.

Мета статті - виявити статеві відмінності у переживанні студентською молоддю психологічної безпеки після сприймання новин зі ЗМІ залежно від індивідуально-типологічних властивостей і базових переконань особистості студентів обох статей.

Виклад основного матеріалу. Для з'ясування того, чи змінюється у студентів різної статі відчуття психологічної безпеки після сприймання новин із мас-медіа, їм було запропоновано відповісти на запитання: «Чи підвищується у Вас відчуття небезпеки після того, як Ви дізналися про новини зі ЗМІ?». Для того, щоб дати відповідь, необхідно було скористатися 10-бальною градуальною шкалою, де 1 - «Ні, відчуття небезпеки не змінюється», а 10 - «Так, відчуття небезпеки зашкалює».

Для виявлення того, звідки студенти різної статі отримують новини та як часто вони контактують зі ЗМІ як із джерелом нових повідомлень, була використана авторська експрес-анкета. Для встановлення змін в емоційній сфері студентів різної статі було застосовано Шкалу ситуативної тривожності Ч. Спілбергера (адаптація Ю. Ханіна). Для визначення особистісних властивостей студентів різної статі, їхніх глибинних уявлень про світ і про себе у світі були використані Індивідуально-типологічний опитувальник Л. Собчик i методика «Шкала базисних переконань особистості» (адаптація М. Падун і А. Котельникової).

У дослідженні взяли участь студенти 3-го - 6-го курсів Національного університету «Чернігівський колегіум» імені Т.Г. Шевченка, які навчаються за спеціальностями «Біологія», «Технологічна освіта», «Фізична культура», «Психологія», «Соціальна робота». Загальна кількість учасників дослідження - 120 осіб, з них 50 чоловіків і 70 жінок віком від 20 до 24 років. Отримані дані було оброблено за допомогою пакету SPSS for Windows 17.0.

Порівняння оцінок студентами різної статі змін у відчутті психологічної безпеки після сприймання новин зі 3МІ за допомогою U-критерію Манна-Уїтні показало відмінність між винесеними оцінками на рівні значущості $\mathrm{p} \leq 0,01$. Встановлено, що жінки частіше переживають підвищення 
відчуття небезпеки після сприймання новин зі ЗМІ (середнє значення по вибірці - 4,2 бали), ніж чоловіки (3,2 бали). Отже, як бачимо, у студентів обох статей відчуття небезпеки після того, як вони дізналися про новини зі 3МI, підвищується до середнього (жінки) і нижче середнього (чоловіки) рівнів. Це свідчить про те, що жінки емоційніше включаються в аналіз змісту повідомлень, активніше переносять нову інформацію на власне життя, інтенсивніше уявляють собі те, як нові події можуть вплинути на них особисто та на їхніх близьких. Як наслідок, це порушує в них відчуття захищеності, знижує здатність опиратися зовнішнім і внутрішнім негативним впливам. У чоловіків відбуваються схожі процеси, але не так яскраво, як у жінок. Також отриманий результат можна розглядати як опосередкований показник того, що українські ЗМІ продукують досить багато інформації, яка містить у собі невизначеність, непередбачуваність, загрозу, що викликає у студентської молоді розгубленість, занепокоєння, страх.

Для того, щоб з'ясувати, з яких каналів студентська молодь обох статей отримує новини, було оброблено дані анкетування респондентів (таблиця 1). Порівняння частоти звернення чоловіків і жінок до різних каналів надходження новин за допомогою критерію хі-квадрат дозволило виявити статистично значущу відмінність на рівні тенденції $(p \leq 0,05)$ щодо такого каналу, як телебачення. Отриманий результат свідчить про те, що жінки частіше звертаються до телебачення як до джерела надходження нових повідомлень, ніж чоловіки. Відносно інших каналів надходження новин не було отримано статистично значущих відмінностей.

Аналіз отриманих результатів свідчить про те, що студентська молодь обох статей здебільшого отримує нові повідомлення або від безпосереднього соціального оточення, яке становить iii постійне коло спілкування (сім'я, друзі, одно- групники), або від таких ЗМІ, як інтернет та телебачення. При цьому роль інтернету як джерела новин $є$ значно вищою, ніж роль телебачення. Водночас, як було зазначено, жінки звертаються до телебачення частіше, ніж чоловіки. Враховуючи особливості подачі новин на телебаченні (драматизм, боротьба інтересів; відхилення від загальноприйнятих норм) та спрямованість телебачення насамперед на емоційні структури психіки телеглядача [8, с. 232-234], стає більш зрозумілим, чому жінки мають білш виражені порушення у переживанні захищеності після сприймання новин зі 3МI, ніж чоловіки.

Порівняння рангувань студентами обох статей різних каналів надходження новин залежно від того, наскільки вони інформативні та варті довіри, дозволило виявити статистично значущу відмінність $(\mathrm{p} \leq 0,05)$ щодо довіри до телебачення. Якщо серед чоловіків показник високої довіри до цього ЗМІ становить $38,9 \%$, то серед жінок $54,1 \%$. Це вказує на те, що жінки більше вірять в об'єктивність висвітлення подій на телебаченні, а також у чесність і неупередженість тележурналістів, ніж чоловіки. Відповідно, висока довіра до цього мас-медіа, яка поєднується 3 частим зверненням до нього, не може не позначитися на переживанні жінками психологічної безпеки. Як вже було зазначено, специфікою впливу телебачення на телеглядача $€$ те, що воно вдається не стільки до механізмів впливу, які грунтуються на логіці, скільки до механізмів, що грунтуються на підключенні до емоційної сфери людини [8, с. 233]. Отже, некритичне сприймання людиною повідомлень зі 3MI, швидке занурення у неприємні переживання може завдати суттєвого удару по її відчуттю психологічної безпеки.

Аналіз відповідей респондентів на запитання анкети: «Як часто Ви звертаєтесь до ЗМІ, щоб дізнатися про новини?» показав, що студенти обох статей або дуже рідко, або дуже часто зверта-

Таблиця 1

Частота звернень студентів обох статей до різних каналів надходження новин (у \% всередині кожної групи студентів)

\begin{tabular}{|l|c|c|}
\hline \multicolumn{1}{|c|}{ Канали надходження новин } & Студенти чоловічої статі & Студенти жіночої статі \\
\hline сім'я & 68 & 70 \\
\hline друзі & 68 & 70 \\
\hline одногрупники & 48 & 40 \\
\hline колеги по роботі & 10 & 14 \\
\hline випадкове оточення & 12 & 13 \\
\hline газети, журнали & 10 & 16 \\
\hline радіо & 8 & 14 \\
\hline телебачення & 36 & 53 \\
\hline сайти новин в інтернет & 70 & 66 \\
\hline соціальні мережі & 82 & 86 \\
\hline
\end{tabular}


ються до 3МІ як до джерела надходження нових повідомлень. Це вказує на те, що вони дізнаються про новини або тоді, коли не досить інформовані про те, що відбувається в країні та світі, або коли надто переобтяжені різною суперечливою інформацією, що також не може не впливати на їхнє відчуття психологічної безпеки. Розподіл відповідей респондентів обох статей на це питання подано в таблиці 2.

Оскільки будь-яка людина відображає навколишню дійсність відповідно до тих психічних структур, які в неї сформовані, було вирішено розкрити деякі психічні властивості студентів обох статей, які опосередковують їхні контакти зі 3МI. Серед них важливе місце займають індивідуально-типологічні властивості та базові переконання особистості.

Проведений кореляційний аналіз даних по чоловічій вибірці показав один статистично достовірний позитивний кореляційний зв'язок між показником підвищення відууття небезпеки після сприймання новин зі 3МI і тривожністю як індивідуально-типологічною властивістю ( $\mathrm{r}=0,320$ при $\rho \leq 0,05)$. Це свідчать про те, що до порушень душевної рівноваги після сприймання новин зі 3МІ схильні насамперед чоловіки, які на рівні особистісної організації характеризуються підвищеною чутливістю до будь-яких змін у навколишньому середовищі. Ці зміни сприймаються як такі, що несуть у собі загрозу усталеному способу життя.

У ситуаціях невизначеності, можливої небезпеки такі чоловіки відчувають безсилля, безпорадність, невпевненість у собі і прагнуть до того, щоб мінімізувати руйнівний вплив переживань на свій внутрішній світ, вдаючись до обмежувальних або попереджувальних дій. Залежно від того, як буде оцінено рівень загрози, ці дії можуть виражатися як у блокуванні активності, так і в хаотичному, позбавленому здорового глузду запобіганні можливій загрозі. Оскільки в сучасному суспільстві основним каналом надходження нових повідомлень про події в країні та світі є 3МІ, цілком імовірно, що для чоловіків із підвищеною особистісною тривожністю контакт із мас-медіа $\epsilon$ постійним джерелом стресу, який регулярно дестабілізує їхнє відчуття психологічної безпеки.

Кореляційний аналіз даних по жіночій вибірці показав кілька статистично достовірних кореляційних зв'язків між показником підвищення відчуття небезпеки після сприймання новин зі 3МI і ситуативною тривожністю, індивідуально-типологічними властивостями «тривожність», «сензитивність», «ригідність», базисними переконаннями особистості «справедливість», «удача». Отримані кореляційні зв’язки по жіночій вибірці наведено в таблиці 3.

Проаналізуємо докладніше виявлені кореляційні зв'язки. Встановлений позитивний кореляційний зв'язок між показником підвищення відчуття небезпеки після сприймання новин зі 3МI i ситуативною тривожністю $(\mathrm{r}=0,677$ при $\rho \leq 0,01)$ вказує на безпосередню реакцію жінок на ті повідомлення, які вони отримують через мас-медіа. Ця реакція включає як осмислення змісту повідомлень, так і емоційний відгук на них.

Якщо жінка сприймає повідомлення зі 3MI як такі, що ускладнюють задоволення їі потреб, загрожують їі інтересам, то тоді вона буде зосереджуватися на подальшому обдумуванні цих повідомлень, фантазуватиме щодо того, як події, про які повідомляють 3МI, можуть позначитися на їі житті. I тоді такі роздуми супроводжуватимуться станом напруженості, занепокоєності, знервованості. Якщо ж повідомлення зі ЗМІ сприймаються як надмірно загрозливі, то тоді реакцією на них може бути страх, який може призвести до порушень уваги, зниження працездатності, підвищення стомлюваності, швидкого виснаження. А це руйнуватиме цілісність психіки, загрожуватиме відчуттю захищеності.

Позитивний кореляційний зв'язок між показником підвищення відчуття небезпеки після сприймання новин зі 3МІ і тривожністю як індивідуально-типологічною властивістю $\quad(\mathrm{r}=0,328$ при $\rho \leq 0,01)$ ми пояснюємо тим, що до порушень у відчутті психологічної безпеки після перегляду новин у 3МІ схильні насамперед жінки, які мають тенденцію оцінювати найрізноманітніші життєві ситуації як небезпечні, загрозливі та реагувати

Таблиця 2

Частота звернення студентів обох статей до різних ЗМІ для отримання новин (у \% для кожної групи окремо)

\begin{tabular}{|l|c|c|}
\hline \multicolumn{1}{|c|}{ Частота звернення до 3МІ } & $\begin{array}{c}\text { Студенти чоловічої } \\
\text { статі }\end{array}$ & Студенти жіночої статі \\
\hline надто рідко (рідше, ніж один раз на тиждень) & 22 & 27 \\
\hline один-два рази на тиждень & 28 & 29 \\
\hline три-чотири рази на тиждень & 14 & 10 \\
\hline майже щодня & 24 & 26 \\
\hline по кілька разів на день & 12 & 8 \\
\hline
\end{tabular}


Таблиця 3

Кореляційні зв'язки між показниками підвищення відчуття небезпеки у жінок та їхніми індивідуально-типологічними властивостями і базисними переконаннями особистості

\begin{tabular}{|l|c|}
\hline $\begin{array}{c}\text { Індивідуально-типологічні властивості, базисні переконан- } \\
\text { ня особистості }\end{array}$ & $\begin{array}{c}\text { Кореляційний зв’язок із показником } \\
\text { відчуття небезпеки після сприймання } \\
\text { новин зі 3MI }\end{array}$ \\
\hline Ситуативна тривожність &, $677^{* *}$ \\
\hline Тривожність як індивідуально-типологічна властивість &, $328^{* *}$ \\
\hline Сензитивність як індивідуально-типологічна властивість &, $280^{*}$ \\
\hline Ригідність як індивідуально-типологічна властивість &, $267 *$ \\
\hline Справедливість як базисне переконання особистості &,$- 252^{*}$ \\
\hline Удача як базисне переконання особистості &,$- 243^{*}$ \\
\hline
\end{tabular}

** - рівень значущості $0,01, *$ - рівень значущості 0,05

на них станом підвищеної тривоги. Такі жінки відчувають тривогу практично в будь-яких ситуаціях, навіть тоді, коли стикаються 3 дрібними буденними проблемами. Вони надмірно чутливі до можливих загроз, схильні до блокування своєї активності або до панічної поведінки, якщо ситуації оцінюються як особливо небезпечні. Закономірно, що 3МІ, висвітлюючи різні події, стають для них джерелом додаткового стресу, провокуючи підвищення тривоги і порушуючи у них відчуття захищеності.

Позитивний кореляційний зв'язок між показником підвищення відчуття небезпеки після сприймання новин зі ЗMI і сензитивністю як індивідуально-типологічною властивістю $(\mathrm{r}=0,280$ при $\rho \leq 0,05)$ свідчить про те, що порушення у відчутті психологічної безпеки після перегляду новин у ЗМІ характерні для тих жінок, які надмірно чутливі до різних впливів, що надходять від середовища, залежні від ставлення до них оточуючих людей, пасивні у подоланні життевих труднощів і перешкод. Такі жінки характеризуються розвиненою емпатійністю, вразливістю, надмірною сприйнятливістю до емоційних станів інших людей. У ситуаціях стресу вони схильні до значних обмежень своєї активності або до підпорядкування більш сильній особі. Отже, повідомлення зі ЗМІ можуть порушувати в них відчуття захищеності, якщо сприймаються як такі, що несуть загрозу як самим жінкам, так i їх значущому мікросередовищу.

Позитивний кореляційний зв'язок між показником підвищення відчуття небезпеки після сприймання новин зі 3МІ і ригідністю як індивідуально-типологічною властивістю $\quad(\mathrm{r}=0,267$ при $\rho \leq 0,05)$ ми пояснюємо тим, що порушення у відчутті психологічної безпеки після перегляду новин у ЗМІ спостерігаються у тих жінок, які схильні повертатися в думках знов і знов до подій, які справили на них сильне враження, тривалий час фіксуватися на своїх переживаннях. Надмірна зосередженість на повідомленнях зі ЗМІ може виражатися не тільки в багатократному проживанні цих подій, але й у пошукові нової інформації про них. Закономірно, що це виснажуватиме психіку таких жінок, негативно позначатиметься на переживанні ними психологічної безпеки.

Негативні кореляційні зв'язки між показником підвищення відчуття небезпеки після сприймання новин зі ЗМІ і базисними переконаннями особистості «справедливість» ( $\mathrm{r}=-0,252$ при $\rho \leq 0,05)$, «удача» $(\mathrm{r}=-0,243$ при $\rho \leq 0,05)$ вказують на те, що до порушень у відчутті психологічної безпеки після перегляду новин у ЗМІ схильні жінки 3 певними уявленнями про світ і про себе у світі. Такі жінки мають сумніви щодо того, що удачі й нещастя, винагороди і покарання розподіляються у світі справедливо, відповідно до того, що «кожний отримує те, на що заслуговує». Також ці жінки не вірять у те, що вони належать до кола осіб, кому таланить і посміхається удача. На наш погляд, зміст другого переконання лише підсилює зміст першого, оскільки жінка, яка вважає себе невезучою, невдачливою, почуватиметься ще більш вразливою у світі, де панує несправедливість. Це лише підсилюватиме в неї внутрішню незахищеність, знижуватиме опір несприятливим впливам.

Висновки. Результати емпіричного дослідження свідчать про те, що сприймання новин зі ЗМІ спричиняє психологічний відгук у студентської молоді обох статей, який, зокрема, виражається у зниженні відчуття психологічної безпеки. Водночас встановлено, що у жінок порушення відчуття психологічної безпеки відбувається інтенсивніше, ніж у чоловіків. Якщо виходити 3 того, що людина під час сприймання новин зі ЗМІ постійно коригує свою взаємодію із середовищем, уявно поміщаючи себе в нові або змінені соціальні умови, то стає оче- 
видним, що студентська молодь жіночої статі більш інтенсивно ототожнює себе з ситуаціями, які висвітлюються в новинах, ніж студентська молодь чоловічої статі.

Також виявлено, що зниження відчуття психологічної безпеки після сприймання новин зі 3МI зумовлюється деякими психологічними характеристиками студентів обох статей: у чоловіків - це підвищена особистісна тривожність, у жінок підвищена ситуативна тривожність, виражені особистісна тривожність, сензитивність, ригідність, слабка віра в справедливість світу і в свою удач- ливість при взаємодії з ним. Загалом встановлено, що до порушення психологічної безпеки після сприймання новин зі ЗМІ схильні насамперед ті жінки, які ще до перегляду новин характеризуються більшою сприйнятливістю до зовнішніх впливів і нижчими внутрішніми ресурсами опиратися цим впливам.

Перспективною подальших досліджень може стати більш глибоке розкриття змін, які відбуваються у когнітивних структурах представників різної статі після сприймання новинних повідомлень зі 3МI.

\section{ЛІТЕРАТУРА}

1. Життєвий світ і психологічні безпека людини в умовах суспільних змін. Реферативний опис роботи / М.М. Слюсаревський, Л.А. Найдьонова, Т.М. Титаренко, В.О. Татенко, П.П. Горностай, О.М. Кочубейник, Б.П. Лазоренко. Київ : Талком, 2020. 318 с.

2. Баева И.А., Баев Н.Н. Психологические ресурсы защищенности студентов как показатель психологической безопасности личности. Электронный журнал «Психологическая наука и образование». 2013. № 1. C. 1-9. URL: http://psyedu.ru/files/articles/psyedu_ru_2013_1_3231.pdf.

3. Бубнова О.В., Куликова О.В. Психологическая безопасность личности как условие социальной адаптации молодых специалистов. Современные проблемы науки и образования. 2015. № 1-1. URL: https://www.science-education.ru/ru/article/view?id=17777.

4. Вербина Г.Г. Психологическая безопасность личности. Вестник Чувашского университета. 2013. № 4. C. 196-202. URL: https://cyberleninka.ru/article/v/psihologicheskaya-bezopasnost-lichnosti.

5. Шевчук Г.Й. Особливості сприйняття телевізійної інформації жіночою аудиторією. Вісник Національної академії Державної прикордонної служби України. 2012. № 5. URL: file:///C:/Users/E8F7 1/ AppData/Local/Temp/Vnadps_2012_5_52-1.pdf.

6. Ржанова И.Е., Алексеева О.С. Различия ценностей мужчин и женщин. Психологические исследования. 2017. Т. 10 № 55. C. 8. URL: http://psystudy.ru/index.php/num/2017v10n55/1479rzhanova55e.html.

7. Харламенкова Н.Е. Половые и гендерные различия в представлениях о психологической безопасности. Социильная психология и общество. 2015. Т. 6. № 2. С. 51-60.

8. Харрис Р. Психология массовых коммуникаций. Санкт-Петербург : Прайм-ЕВРОЗНАК, 2002. 448 с.

\section{REFERENCES}

1. Slysarevsky M.M., Naydonova L.A., Tytarenko T.M., Tatenko V.O., Gornostai P.P., Kochubeynyk O.M., Lazorenko B.P. (2020) Zhyttievyi svit i psykholohichni bezpeka liudyny v umovakh suspilnykh zmin. Referatyvnyi opys roboty [The vital world and psychological safety of the person in the conditions of social changes]. Kyiv : Talkom [in Ukrainian].

2. Baeva I.A., Baev N.N. (2013) Psikhologicheskiye resursy zashchishchennosti studentov kak pokazatel psikhologicheskoy bezopasnosti lichnosti [Psychological resources of students' safety as an indicator of psychological security of an individual]. Elektronnyy zhurnal "Psikhologicheskaya nauka i obrazovaniye" - Electronic journal "Psychological-Educational Studies". 1, 1-9. Retrieved from http://psyedu.ru/files/articles/psyedu_ru_2013_1_3231.pdf [in Russian].

3. Bubnova O.V., Kulikova O.V. (2015) Psikhologicheskaya bezopasnost lichnosti kak usloviye sotsialnoy adaptatsii molodykh spetsialistov [Psychological safety of a personality as a condition of socio-environmental adaptation of young specialists]. Sovremennyye problemy nauki i obrazovaniya - Modern Problems of Science and Education. 1-1. Retrieved from: https://www.science-education.ru/ru/article/ view?id=17777 [in Russian].

4. Verbina G.G. (2013) Psikhologicheskaya bezopasnost lichnosti [Psychological safety of the person]. Vestnik Chuvashskogo universiteta - Bulletin of Chuvash State University. 4, 196-202. Retrieved from https://cyberleninka.ru/article/v/psihologicheskaya-bezopasnost-lichnosti [in Russian].

5. Shevchuk H.I. (2012) Osoblyvosti spryiniattia televiziinoi informatsii zhinochoiu audytoriieiu [Specific features of perceiving television information by female audience]. Visnyk Natsionalnoi akademii Derzhavnoi prykordonnoi sluzhby Ukrainy - Bulletin of the National Academy of the State Border Guard 
Service of Ukraine. 5. Retrieved from file://C:/Users/E8F7 1/AppData/Local/Temp/Vnadps_2012_5_ 52-1.pdf [in Ukrainian].

6. Rzhanova I.E., Alekseyeva O.S. (2017) Razlichiya tsennostey muzhchin i zhenshchin [Differences in values between men and women]. Psikhologicheskiye issledovaniya - Psychology studies. 55 (10), 8. Retrieved from http://psystudy.ru/index.php/num/2017v10n55/1479-rzhanova55e.html [in Russian].

7. Kharlamenkova N.E. (2015) Polovyye i gendernyye razlichiya v predstavleniyakh o psikhologicheskoy bezopasnosti [Sex and gender differences in perceptions of psychological safety]. Sotsialnaya psikhologiya i obshchestvo - Social psychology and society. 2 (6), 51-60 [in Russian].

8. Kharris R. (2002) Psikhologiya massovykh kommunikatsiy [Psychology of Mass Communication]. Sankt-Peterburg : Praym-EVROZNAK [in Russian]. 